\title{
Parenting Cooperative Model
}

\author{
Syur'aini \\ Universitas Negeri Padang, Padang, Indonesia \\ e-mail: syurainipls@gmail.com
}

\begin{abstract}
This research starting from the parents awareness in the students activities had been facilitated by a teacher. That condition make an inharmonious learning situation between teacher in the school (PAUD) with the parents in home. The research objectives is to find a model of parenting cooperative that had done by a teacher with parents on the TK 'Aisyiyah 6 Padang. A qualitative approach used by researcher especially on case study design. Informance of this research are school principal, teacher and parents. An observation technique, interview and documentation used by researcher as a effectively method for data collecting. Data analysis that used in this research is descriptive technique, consist of data reduction, display of data, and the last is making a research conclusion. Data verification in this research consist of four criteria are credibility, trasferability, dependability, and confirmability. Research finding told us that parenting cooperative model that used by a taeacher with the parents on TK 'Aisyiyah 6 is "Model 3S: Senang, Santai, Selesai". The meaning of this model is would told us that a cooperative activities had been done but did not maximum yet till now.
\end{abstract}

Keywords: Cooperative, parenting

\section{INTRODUCTION}

Family, school and society as a three environments that create human become an individual educated. The three kinds of educational environment called by Ki Hajar Dewantara [1] as a "tripusat education" are environmental family, environmental college, and environment of youth. According from [2] the responsibilities done together by parents, teachers, and communities on: 1) helping for teaching, educating, developing childrens for becoming a qualifed individuals and highly integrity, 2) taking role of education and developing all of intelligencies aspect yang dapat diandalkan, 3) watching and controlling childern behaviour and thinking about children futures become successful individual and had a highly social spirit.

For achieving an optimum educational outcomes need a good accompaniment from the three kinds of the educational environment. Especially for Early Childhood (AUD), educational process more conducted by their parents in the family and other family members likes grandmother, grandfather, elder brother, uncle, aunt, aides and everyone who lives around the family, that would influencing their future. Therefore their parents should be more involved in the early childhood education.

Teacher and parents to design an activity that can result in specific ways and easy in stimulating the development of children [3]. This activity is expected to help teachers and parents in carrying out their duties as educators. This arduous task of educators both teachers and parents, but very noble and useful for the life of the child later.

If the observed current conditions between parents and teachers in educating children has not kept pace so that there was inequality in children's education action. Teachers implement curriculum education in accordance with the prescribed methods and techniques learned and according to early childhood learning. While parents implement appropriate education in ways that generally obtained for generations of parents and their relatives. Where acceptable ways that are often incompatible with science education. The lack serasian can be caused by many things including: (1) The teacher does not carry out the competence of social good, (2) lack of a program that brings together the ways and techniques to educate the teachers and parents, (3) lack of knowledge of parents in educating children, (4) lack of time parents have in educating children, (5) teachers and parents think about the need for cooperation in childcare.

Teachers should be aware that he has the ability and social responsibility as set out in the social competence of teachers. In this case the teacher must apply social competence in item 3 is the ability to collaborate, both individually and in groups with parents [4]. In line with that in the Framework for Early Childhood Education and Curriculum Structure 2013 stated that one of the characteristics of the curriculum in 2013 was to empower the role 
of parents in the learning process. This means that parents should together with teachers in educating children and teachers should have a program that can bring together parents in educating children.

In reality a partnership between parents and teachers is very less. Parents are not much involved in the learning activities. In case [5] "cooperation between teachers, students and parents is like a circle that will never break." This means that between parents and teachers should always carry out efforts to develop the potential of children together. This can be done in a parenting partnership between teachers and parents, where parents do care at home have the same principle in education conducted in early childhood teacher.

When observed conditions in the field of early childhood education institutions already carrying out sebahagian cooperation and intensive parenting but have not yet programmed properly. This has an impact to the attention of parents is lacking in the activities held at the school. Moreover, parents are also more preoccupied with work outside the home to meet basic needs, such as food, clothing, and other needs. They have little time and energy to think about how to improve their child's development [6].

In contrast to the study carried out in general parents in the past, especially in Minangkabau. Although parents when it was still a lot that are not highly educated and some have never tasted formal education but parents really trust the teachers in the school or the teacher in the Koran. Parents drove their children to educational institutions also submit their children's education in full to the teacher. Parents never asks if teachers give punishment to their children. Even his parents when he handed over to the non-formal education as to the mosque to recite or studied religion then the parents provide a bundle of stick/cane as both Palembang that the parent fully assign responsibility for their children's education to teachers.

Noting past educational cultural phenomenon as described above is certainly no longer suitable for today. Educational paradigm had changed from teacher centered to learner approach centered.

Based on the background of the problems outlined above, the research trying to find a cooperation model parenting implemented by teachers with parents of students in kindergarten 'Aisyiyah Padang. Based on this model will be developed after the analysis is more suitable model.

\section{METHODS}

This study was designed in the form of qualitative research with case study type. The research was conducted in kindergarten 'Aisyiyah 6 Padang Ulak Karang. The informants consist of principals as key informants, then teachers, and parents. Informants were selected according to the type of data that is required in this study.

The data collection is done by several techniques, namely: Observation; researchers observed parents, principals, teachers and children (informant) that are interacting and observing the behavior that appears. Observations directed to all the activities principals, teachers, parents and neighbor interaction. To be directed by good observation the researchers used a sheet / observation for the next made field notes.

Interview; Researchers conducted interviews with informants related to the implementation of parenting that do principals, teachers and parents. This technique is used to supplement the data obtained by observation in order to obtain the data that is broader and more complete. Data collection tool used interview guides and tape recorders as a data recording device.

Documentation; Researchers studied several documents related to the cooperation of parenting such as the annual activity plan of the school, the data existing child in the teacher's notes, the teacher data contained in the principal, and the data of parents contained in the main book and a registration form and record the progress of development of the child is on teacher.

Data collection was conducted with a qualitative approach. Because the data analysis is consistent with qualitative research is a cyclical [7]. Thus it can be said that the data analysis activities can not be separated from data collection activities [8], could been done during a field process and after was coming from the fields of study by [9], conducted during the field and return from the field.

Further data analysis is using descriptive technique as recommended by [10], is to perform data reduction, data presentation, and conclusion.

Examination of the validity of the data in this study using four criteria as advocated by [11] and [12], namely: (1) The credibility (internal validity), (2) tranferabilitas (external validity), (3) dependability (reliability), and (4) confirmability (Objectivity).

Credibility: to obtain credibility of the data, do some engineering, namely tri-anggulasi, peer examinations, and checking members (member check).

Transferability: to be able to build transferability (keteralihan) the findings of this study to other 
contexts the same or almost the same with the context of this study, presented a detailed description. As implied by its name, then in building keteralihan, researchers report the results of this study as precisely and completely as possible, which describes the context and the subject matter clearly.

Dependability: in order to establish the dependence of data obtained reports, do penulusuran through auditing. For that presented the results of research and methods, as well as the files of research activities. Based on the presentation, requested the help of auditors to determine whether the research findings related to traces of field activities as recorded in the entire field notes.

Confirmability: to provide the confirmation about the certainty of the data obtained, will be audited dependence, examination of internal coherence in the presentation, interpretation, and conclusions of the study. This study is limited to cooperation in social development andearly childhood emotion. While the location is limited research on Kindergarten 'Aisyiyah 6 Padang Ulak Karang.

\section{RESULT OF RESEARCH}

The results showed that teachers and principals are already implementing a parenting partnership with parents. But parenting cooperation is much yet to be implemented programmatically and have not touched all the needs of both parties that teachers and parents. There are some things that are found associated with the model of cooperation of teachers with parents include: (1) Planning includes: idetifikasi needs and learning resources, alternative program, selection of the program; (2) Implementation of the partnership include: forms of cooperation, material cooperation and joint execution time; (3) Assessment program includes: assessment process and results.

\subsection{Planning}

In identifying the needs and learning resources as well as choosing a program, principals do this by presenting the parents at the beginning of the school year to deliver parenting programs without asking enter or suggestions from parents. Delivering the form of programs, execution time, and the program material that has been made by the school principal and teachers. Program delivery is done orally along with other important information. Teachers and parents only agree on timing of meetings every month.

\subsection{Implementation}

\subsubsection{Partnership forms Parenting}

Parenting activities that have been carried out in this school there are several forms: The first form of monthly meetings / regular meetings. The monthly meeting begins with a parent meeting in the first month of the second week of the children in school at the beginning of the school year. This meeting is mandatory for all parents of students studying in the kindergarten without exception. This meeting aims to interact with parents about education conducted in educational institutions ie kindergartens Aisyiyah 6. When parents are unable to attend shall be represented by one of the family members who daily get along with the children.

A part from the discussion of education programs, meeting at the beginning of the year also talked about the regulations that apply in school such as school attendance and returning from school. Telling a teacher about the importance of the presence of children in accordance with the schedule set "if the child is often late escorted by their parents, children can be sad even so inferior to his friends. Sometimes the child is difficult to get along with his friend, aloof. For some children do not want to come too late, when it was too late she did not want to come in and do not want to join his friends ". To schedule a home is usually no teachers picket in the school yard return of a child to remove and return the child to his parents, shaking hands with the teacher.

Second,The anniversary Mass, held a few times a year according to the number of children whose birthday is around 20 people. The birthday celebration was attended by parents and other family parties. Anniversary program prepared by the school in collaboration with the birthday child's parents. The anniversary was also celebrated with the distribution of gifts in the form of snacks and small cakes to all children present. The event ended with a group photo of children birthdays and photos with their respective families.

Third, The event closed the year is done a few days before the end of the school year. The event closed the year filled with activities the appearance of each child's skill as rote short letters, read a prayer, the call to prayer, reciting poems, singing, dancing, fantomim, fashion shows and choir. Before the show closed in a meeting with the parents. This meeting is to talk about the form of 
presentation of each child. Teachers drafted the activities and performance of each child according to the child's ability and willingness. Teachers communicate to parents when meeting with parents. If there are parents who do not agree should make a proposal in accordance with the talents and interests of children.

Fourth, form other activities such as field trips to museums and that is to place the fire department. Fifth, a race organized by the Association of Kindergarten Teachers (IGTK) and the rituals of Hajj activities organized by the Association of Teachers Bustanul RA (IGABA).

\subsubsection{Parenting Material}

Meetings with parents are held every month to discuss about the rules that exist in schools. The norm of question include tuition payment schedule every month so as not to pass through the 10th, the schedule entry and departure of children every day does not exceed the appointed hour. Material meeting also charged with delivery problems encountered pupil at the school in general. All the rules and the problems presented in the parents verbally. These talks are generally intended to remind parents to be his duty to the educational institutions, especially in relation to finance and education problems of children.

Meetings with parents is also charged with gathering and eating with parents. Gathering only attended by several parents who are willing. For parents who are not willing to participate arisan not enforced. This gathering was well received by parents. More than half of parents follow this social gathering. Social gathering social gathering held in the form of money 10 thousand rupiah per month. Ibuk-ibuk very eager to follow a social gathering because apart from feasting also listen to the information from the school and receive social gathering that greatly help parents financially.

The introduction of the curriculum to parents in general terms only and does not introduce the theme. The headmaster felt no need to do that because there is no benefit for parents and this has been common practice since time immemorial.

\subsubsection{The timing of the cooperative parenting}

The research findings show that the time spent in activities with their parents only on
Saturdays second week of each month. Cooperation that has been programmed by the principal / teacher is a monthly meeting. Monthly meetings held once a month in the form of a meeting with parents. Results of interviews with principals and some teachers declared the second week of every month there is a meeting with parents. This meeting is usually made one hour before the end of learning in schools. Have time for considering the presence of parents at the school to pick up their children at the same time. Thus does not take a lot of time for parents. In this meeting the principal, accompanied by one teacher alternately every month. This is done because the school did not want to be bothered learning in school and learning continue to run as usual.

The research findings have been disclosed above can depicts the timing of parenting activities programmed only once in a month on Saturday the second week. Forms of parenting programs that do are in the form of monthly meetings, birthdays and events bulk material whereas the closing years of the program is the delivery of important information, remind the obligation to pay the tuition, delivering overall child issues and social gathering for parents who are willing. Overview results of this study mean that parenting cooperation conducted by teachers and principals has not been maximized and yet accommodate the needs of teachers and parents in educating early childhood both in terms of time, courses and learning materials. For more details can be observed in a model in the following figure: 


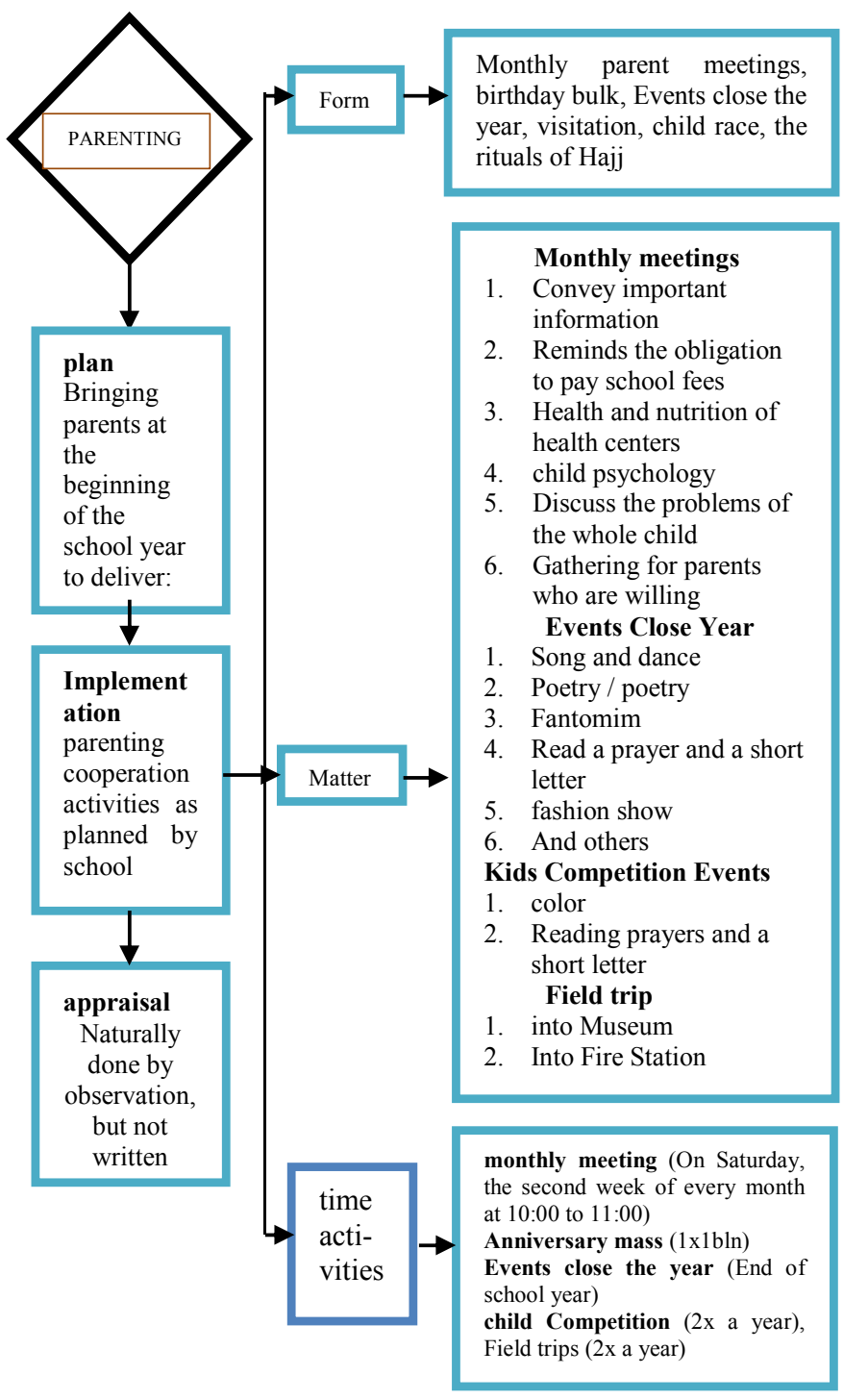

Figure 1. Cooperation Model Parenting Performed by Master with Parents

Cooperation model is found byobservation and interviews as has been described above it can be concluded that the teacher has not done parenting cooperation activities with appropriate programmatic and systematic program management measures. teachers todaythismore perform routine activities necessary to help smooth the task of teachers in educational institutions. Teacher not yet have a programmable maximum effort to foster the achievement of development of the child. Teachers are not many involve parents in program management, especially in planning the program, especially in identifying needs and learning resources owned by the parent. Teachers have not conducted an assessment of program activities with good parenting. Teachers do more activities as in previous years and few hold renewal. The findings of this study can be named with the cooperation model $3 \mathrm{~S}$ (Happy, Relaxed, Completed). 3S means that teachers are doing activities with pleasure because it is a routine task as a teacher, but the teacher did not think too much relaxed efforts are complicated and innovative in order to increase participation and parents' ability to develop potentialchild, This is implemented teacher until the school year is finished and the children go to primary school.

\section{DISCUSSION}

Parenting cooperation between teachers and parents in early childhood 'Aisyiyah 6 have long done. This activity is carried out in various forms but not many involve parents. Based on the data collected parenting cooperation model implemented early childhood educators with parents can be named with the model 3S (Happy, Relaxed, Completed). 3S means that teachers are doing activities with pleasure because it is a routine task as a teacher, but the teacher did not think too much relaxed efforts are complicated and innovative in order to increase the participation of parents in developing the potential of children. This is implemented teacher until the school year is finished and the children go to primary school.

\subsection{Planning}

Teacher not yet have a programmable maximum effort in promoting the achievement of the development of the child. This means that existing activities has not been designed specifically for the purpose or attempt to develop children's potential to the fullest [13]. Activities that do more to meet with parents for the problems that occur without a clear program planning and measurable and can be beneficial to both parties that parents and teachers [14]. The material has not touched the program needs holistically teachers and parents in educating children. This case could be happen because before done need identification as a first step in the program planning. [15] said that for getting purpose of program had done the need assessment for taking information about learner needs. 


\subsection{Implementation}

Cooperation model based on observations and interviews found that visits from three sub variables form of programs, materials and time program execution with the following procedure: first principals and teachers held a meeting with parents in the early weeks of learning. In the beginning of the meeting presented the plan the next meeting include: the timing of activities, programs and materials form the program planned by the school principal and teachers. The principal asks that parents can attend a meeting in the next months. Both principals meet every month as a time agreed in the first but the material more meetings to discuss the problems of children and financial payments [16].

First, Shape parenting program has not varied so that the programs offered are not attractive. Teachers today do more routine activities are necessary to help smooth the task of teachers in educational institutions. This is contrary to what the [17] that the participation of parents in the school in general to improve the performance of children in school and if the school has a good program, and parents want to help, generally achievement and skills of children will increase [18]. This opinion adds to our belief that greater participation of parents will bring benefits in the social and emotional development of children. If the child has entered school, the parent is the main partner for their teachers.

If only teachers make are varied program will be an attraction for parents. There are so many forms of programs that can be followed as proposed by the expert that the parenting cooperation activities that can be done include: think-tank (brainstorming), gathering to speak, seminars, practice skills, outbound, field trips. Indeed, parents have many options to do the role, such as students, volunteers, decision makers and as a team member of cooperation between teachers and parents. That role may help improve the social and emotional development and the full potential of their child [17]. The participation and high parental participation at the school following the parenting program is an indicator of the high quality of the offered programs. The better the growing number of programs implemented in the program. Pupil gets better when parents visit the school and communicate with teachers about what is happening with their children and participate in activities held at the school. It can be seen from what is disclosed in the standard of education according to the Department of Education (2005):

"A high level of family involvement is an indicator of a high quality program. Children benefit when family members are invited to Participate in ongoing communication about what is happening in their child's early childhood education and care through discussions with caregivers, parent-teacher conferences, open houses, parent-child activity times, parent education, transition-to- kindergarten sessions, and volunteer opportunities. Information about developmental Widely held expectations can be shared with parents during Reviews These times".

High family participation in activities held in educational institutions is an indicator of highquality programs. Children benefit when parents are invited to participate and communicate about what happened to their child. Parents can discuss with caregivers, seminars, open hous, along with parent and child activities, parent training, or as volunteers. Information on child development can be shared with parents during a meeting with the teacher.

Aside from the forms of cooperation parenting described above, there is still the possibility of other forms that can be implemented. Form the cooperation of teachers with parents in children's education can be done in two forms of non-formal and informal education, Non-formal education can take the form giving exercise to the parents (parenting training) whereas in informal education can shape the creation of independent learning atmosphere and their mutual learning among fellow parents. This is done in order to increase knowledge and skills of parents and in order to equate the concept of parenting. In this way the expected similarities in education and care action so it does not make children become confused.

Previous quote describes the participation of parents in the various activities held in the school will have a positive effect on children's development. Family members need to know what happened to his son, to discuss with the teacher, can carry out activities together with pupils and parents can also be a volunteer or simply as an observer only. Everything is going to give kindness to the education of children with parents and teachers to implement the requirements with pleasure, full of sincerity, seriously and with enthusiasm in the struggle to educate children not in a relaxed manner 
without even thinking about new things and without willing to work hard.

Second, Parents learning materials needed such as social and emotional development of young children, tips inculcate good social and emotional, the principles of early childhood learning and others who needed parents had not accommodated well in meetings. Children who had a better performance from their parents who had better knowledge and behavior [19]. Model of cooperation that do not yet adequate to maximize the social and emotional development of children. In terms of social and emotional development of children conducted since early will have a major influence once the child grows up.

Research shows the close relationship between emotional social development with the success of a person's future. [20] found a strong correlation between their social abilities emotions of childhood as unable to deal with frustration, control emotions, and sociable with others more demonstrated success in the field of socio-economic and employment future success in adulthood. This means that the emotional social intelligence greatly affect one's success in the future. When this intelligence sharpened since an early age will bring great influence during later life such research has been conducted by experts.

Results of thought [21] interpersonal intelligence (social) is the ability to understand other people, what motivates them, how to work shoulder to shoulder with them, successful salespeople, politicians, teachers, doctors, all of them being tend to be people who have the social intelligence is high [22]. Parents who are patient with their mistakes are made, helping the child to try a game in its own way, instead of imposing their will, have a very broad impact on the skills to get along with others. Besides, it also shows more affection to their parents, children are becoming more popular and more preferably among his friends.

So many positive impacts social and emotional development of children in the life of society and the success of the child as an adult of course requires that parents develop social and emotional intelligence since an early age. Material cooperation with parents teachers should be directed to meeting the needs of parents will be social and emotional development of children. Childern intellegencies need parents participation had direct effect for children achievement [23] and needs respect for each other, partnership, responsibilities and negotiation [24].

In terms of the time it turns out, many parents are not able to be present at a specified time. Sebahagian parents have reason to work but if payed job of parenting, there are still many who do not work, especially mothers. Thus the weight of allegations that the absence of parents in activities that have been offered are closely related to several things diataranya: the ignorance of parents about the importance of cooperation with teachers in educating children, the ignorance of the parents about the importance of early childhood education, and less berfariasinya program parenting do so not attractive to parents.

\section{CONCLUSIONS}

The following end this paper will be presented conclusions and suggestions from the results and discussion that has been mentioned earlier. Parenting cooperation undertaken so far by teachers with parents in early childhood education is still not adequate to accommodate the concerns and aspirations of the senior ineducating children. Parenting cooperation program which was held not meet the need felt by both parties that the parents and teachers. Parents still do not have a high willingness to explore the science and experience of teachers in early childhood education as well as teachers have many parents utilize in developing the potential of children. When the two are combined in the form of cooperative parenting that both parents and teachers alike to reap the benefits. It is therefore recommended to the department that oversees early childhood education to give special attention will be cooperative parenting program that can touch the needs of parents and teachers. ECD overseers should motivate parents to be fully involved in all the activities held in early childhood. Principals to create programs that can involve parents in early childhood learning.

\section{REFERENCES}

[1] U. Sadulloh and Dkk, Pedagogik. Bandung: Cipta Utama, 2007.

[2] E. B. Surbakti, Parenting Anak-anak. Jakarta: Elex Media Komputindo, 2012.

[3] Y. N. Sujiono, Konsep dasar pendidikan anak usia dini. Jakarta: PT indeks, 2009.

[4] W. Sanjaya, Strategi Pembelajaran Berorientasi Standar Proses Pembelajaran. 
Jakarta: Kencana Prenada Media Group, 2008.

[5] M. Yamin and J. S. Sanan, Panduan pendidikan anak usia dini. Jakarta: Gaung Persada, 2010.

[6] J. E. Ormrod, Psikologi Pendidikan Membantu Siswa Tumbuh dan Berkembang. Jakarta: Penerbit Erlangga, 2009.

[7] Sugiyono, Metode Penelitian Kuantitatif Kualitatif dan R\&D. Bandung: Alfabeta, 2012.

[8] W. Mantja, Etnografi Desain Penelitian Kualitatif Pendidikan dan Manajemen Pendidikan. Malang: Elang Mas, 2007.

[9] R. Bogdan and S. K. Biklen, Qualitative Research for Education: An Introduction to Theory and Methods. Boston: Allyn and Bacon, 1990.

[10] M. B. Miles and A. M. Huberman, Qualitative Data Analysis: A Sourcebook of New Methods. London: SAGE Publications Ltd, 1994.

[11] Y. S. Lincoln and E. G. Guba, Naturalistic Inquiry, vol. 75. London: SAGE Publications, 1985.

[12] S. Soegiyanto, "Penelitian Kualitatif, Teori dan Aplikasi." Pusat Penelitian IKIP Surabaya, Surabaya, 1990.

[13] R. Lev-wiesel, A. Besser, and R. Laish, "Measuring Potency Among Preschool Children : Instruments and Intervention," Child Adolesc. Soc. Work J., 2005.

[14] J. Guryan, E. Hurst, and M. Kearney, "Parental Education and Parental Time with Children," J. Econ. Perspect., vol. 22, no. 3, pp. 23-46, 2008.

[15] K. Walker, "Needs Assessment. Research Brief.," Educ. Partnerships, Inc., 2007.

[16] P. Webley and E. K. Nyhus, "Parents' influence on children's future orientation and saving," J. Econ. Psychol., vol. 27, no. 1, pp. 140-164, 2006.

[17] S. Patmonodewo, Pendidikan Anak Prasekolah. Jakarta: Rineka Cipta, 2003.

[18] E. V.-D. Nermeen E. El Nokali, Heather J. Bachman, "Parent Involvement and Children's Academic and Social Development in Elementary School," US Natl. Libr. Med. Natl. Institutes Heal., vol. 81, no. 3, pp. 988-1005, 2010.

[19] É. Rochette and A. Bernier, "Parenting, Family Socioeconomic Status, and Child Executive Functioning: A Longitudinal Study," Merrill. Palmer. Q., vol. 60, no. 4, 2014.

[20] D. Goleman, Kecerdasan Emosional. Jakarta: Gramedia Pustaka Utama, 2000.

[21] H. Gardner, Multiple Intelligences, vol. 5, no. 7. New York: Basic Books, 1993.

[22] D. Goleman, Social iIntelligence: Ilmu Baru tentang Hubungan Antar-Manusia. Jakarta:
Gramedia Pustaka Utama, 2007.

[23] M. M. Englund, A. E. Luckner, G. J. L. Whaley, and B. Egeland, "Children's Achievement in Early Elementary School: Longitudinal Effects of Parental Involvement, Expectations, and Quality of Assistance," vol. 96, no. 4, pp. 723-730, 2004.

[24] M. Riojas-cortez, B. B. Flores, and E. R. Clark, "Valuing and Connecting Home Cultural Knowledge with an Early Childhood Program," Young Child., vol. 58, no. 6, pp. 16, 2003. 